\title{
Analysis of the proximate composition and energy values of two varieties of onion (Allium cepa L.) bulbs of different origin: A comparative study
}

\author{
Shovon Bhattacharjee ${ }^{1,}$, Abida Sultana ${ }^{1}$, Muhammad Hasnan Sazzad ${ }^{1}$, \\ Muhammed Ariful Islam ${ }^{1}$, M. M. Ahtashom ${ }^{1}$, Asaduzzaman ${ }^{2}$ \\ ${ }^{1}$ Department of Applied Chemistry and Chemical Engineering, Noakhali Science and Technology University, Noakhali, Bangladesh \\ ${ }^{2}$ Scientific Officer, IFST, Bangladesh Council of Scientific and Industrial Research, Dhaka, Bangladesh
}

\section{Email address:}

shovon_nstu@yahoo.com (S. Bhattacharjee), abida_acce@yahoo.com (A. Sultana), engsazzad23@yahoo.com (M. H. Sazzad), cmiarief@gmail.com (M. A. Islam), evan.ctg@gmail.com (M. M. Ahtashom), asad.acce@gmail.com (Asaduzzaman)

\section{To cite this article:}

Shovon Bhattacharjee, Abida Sultana, Muhammad Hasnan Sazzad, Muhammed Ariful Islam, M. M. Ahtashom, Asaduzzaman. Analysis of the Proximate Composition and Energy Values of Two Varieties of Onion (Allium Cepa L.) Bulbs of Different Origin: A Comparative Study. International Journal of Nutrition and Food Sciences. Vol. 2, No. 5, 2013, pp. 246-253. doi: 10.11648/j.ijnfs.20130205.16

\begin{abstract}
Due to its significant medicinal property, nutritional worth and energy value, onions (Allium cepa L.) impart numerous health benefits to users. The comparative study was conducted to investigate the proximate composition, mineral composition and energy value of red onions of Bangladeshi and Indian origin. Results of studied onion varieties showed that, both Bangladeshi and Indian onions have high amount of Moisture (82.99 \% and $82.77 \%$ ), Carbohydrate $(14.146 \%$ and $14.772 \%$ ), Total Sugar (4.74 \% and $2.32 \%$ ), Vitamin-C (6.5 mg and $5.7 \mathrm{mg}), \mathrm{Ca}(46.9 \mathrm{mg}$ and $25.7 \mathrm{mg}), \mathrm{P}(50.6 \mathrm{mg}$ and $30.3 \mathrm{mg}$ ) and $\mathrm{K}(140 \mathrm{mg}$ and $129 \mathrm{mg})$ respectively. The level of Protein $(2.62 \%$ and $1.489 \%)$, Fat $(0.4 \%$ and $0.721 \%), \mathrm{Fe}(0.6 \mathrm{mg}$ and $0.24 \mathrm{mg}), \mathrm{Cu}(0.04 \mathrm{mg}$ and $0.1 \mathrm{mg}), \mathrm{Mn}(0.2 \mathrm{mg}$ and $0.14 \mathrm{mg})$ and $\mathrm{Zn}(0.2 \mathrm{mg}$ and $0.4 \mathrm{mg})$ are comparatively lower in the varieties. Presence of Protein, Fiber, Sugar, Vitamin-C, Ca, P, Na, K, Fe are considerably higher in Bangladeshi onions than the onions of Indian origin. In contrast, Indian onion has higher amount of fat and $\mathrm{Zn}$. The levels of Carbohydrate, Silica and Ash content are almost identical in both varieties. The result obtained confirmed the usefulness and utility of onion bulbs of both varieties. The result also suggests that Bangladeshi onion having adequate quantity of vitamins and minerals with potentials to meet the nutritional requirements of human health is better than the onion of Indian origin.
\end{abstract}

Keywords: Onion, Origin, Proximate Analysis, Energy Value, Chemical Composition, Nutritional Worth

\section{Introduction}

Onions (Allium cepa L.) are a natural part of the daily diet for most of the population and are a crop of great economic importance in all over the world [1]. It has been used as an ingredient in various dishes for thousands of years by many cultures around the world. In Bangladesh, onion (red) is the most important crop among the spices and is an integral part of diet. It is also used in almost all food preparation [2]. It is cultivated almost throughout Bangladesh and ranks first in production among the species [3].

Not only does the vegetable lend an excellent taste to dishes, but also is associated with imparting a number of health benefits to its users. As numerous health benefits have been attributed to onions, it has been used traditionally in Asia as well as in different parts of the world as medicine [4]. It can protect against cancer, fight fungi and bacteria, promote cardiovascular health, reduce high blood pressure and insulin resistance, aid in weight loss, possess antioxidant activity, fight chronic bronchitis, infections, fever etc. [5-7].

Apart from its value as a natural medicine, it is used as a spice and important ingredient in food due to its nutritive value, aroma, flavor and pungency, as well as preservative qualities. Depending of the origin, the nutritive value (amount of different nutrients present) and energy value of onions varies to a considerable extent [8]. So, there is a need for systematic study to assess the nutritive values of different varieties of onion from different origin.

Each onion of different origin has basic nutritional 
importance that can be assessed by their content of protein, carbohydrates, fats, oils, minerals, vitamins etc. Thus, understanding of the overall composition and nutritional worth of the onions is required to determine its potentials as a food and therapeutic agent [9]. In this study, chemical composition and nutritional worth of red onions of Bangladeshi and Indian origin has been analyzed.

The objectives of our study were to evaluate the proximate composition, mineral composition and energy value of red onions of Bangladeshi and Indian origin. These data provides information, which can be utilized for the comparative assessment of nutritional worth and medicinal property of onions of different origin.

\section{Experimental Methods}

\subsection{Sample Preparation}

Raw red onions of two varieties (Bangladeshi and Indian) were bought from a local market in Dhaka, Bangladesh. The purchased raw onion bulbs were fresh without any physical defect. The outer skins \& ends of the onion samples were removed and washed in running tap water to remove adhering debris. Then, the samples were sliced into chips and dried in an oven at a temperature of $60{ }^{\circ} \mathrm{C}$ for 48 hours. After drying the chips were grinded into fine powder by using a commercial blender. The powdered samples were stored into an air tight bottle in freeze (about $4{ }^{\circ} \mathrm{C}$ ) until further analysis.

\subsection{Determination of Proximate Composition of Onion Samples}

Proximate Composition (Total Moisture Content, Crude Protein, Crude Fat, Crude Fiber, Total Sugar, Vitamin-C, Ash Content, Silica and Total Carbohydrate) of the two varieties of raw onions were determined by the following methods-

\subsubsection{Determination of Total Moisture Content}

The moisture content of powdered onion sample was determined in an oven through drying method (at $105{ }^{\circ} \mathrm{C}$ ) according to the procedure described in AACC (2000) Method No. 44-15A. The moisture content of the sample was determined by weighing $2 \mathrm{~g}$ of sample into a pre-weighed china dish and drying it in an air forced draft oven at a temperature of $105 \pm 5^{\circ} \mathrm{C}$ till the constant weight of dry matter was obtained [10]. The moisture content in the sample was determined as follows-

$$
\begin{gathered}
\text { Moisture }(\%)=[\{(\mathrm{Wt} \text {. of original sample }-\mathrm{Wt} \text {. of dried } \\
\text { sample }) / \mathrm{Wt} \text {. of original sample }\} \times 100]
\end{gathered}
$$

\subsubsection{Determination of Crude Proteins}

The powdered onion sample was tested for crude protein content according to the Kjeldahl's method as described in AOAC, which involved protein digestion and distillation.

Protein Digestion: About $2.0 \mathrm{~g}$ of the sample was weighed into an ash less filter paper and put into a $250 \mathrm{ml}$
Kjeldahl flask. Then, $1 \mathrm{~g}$ of digestion mixture (as catalyst) and $15-20 \mathrm{ml}$ of $98 \%$ conc. Sulfuric acid were added. The whole mixture was subjected to heating in the digestion chamber until transparent residue contents were obtained. Then, it was allowed to cool. After cooling, the digest was transferred into a $100 \mathrm{ml}$ volumetric flask and made up to the mark with distilled water and then distilled using Markham distillation apparatus.

Protein Distillation: Before use, the Markham distillation apparatus was steamed through for 15 min after which a $100 \mathrm{ml}$ conical flask containing $5 \mathrm{ml}$ of $2 \%$ boric acid and 1 or 2 drops of mixed indicator was placed under the condenser such that the condenser tip was under the liquid. About $5.0 \mathrm{ml}$ of the digest was pipetted into the body of the apparatus via a small funnel aperture. The digest was washed down with distilled water followed by addition of 3-4 drops of phenolphthalein and $5 \mathrm{ml}$ of $40 \%$ (W/V) $\mathrm{NaOH}$ solution. The digest in the condenser was steamed through until enough ammonium sulfate was collected. The Boric acid plus indicator solution changed color from red to green showing that all the ammonia liberated had been trapped. The solution in the receiving flask was titrated with $0.063 \mathrm{~N}$ hydrochloric acid upto a purple end point. Also, a blank was run through along with the sample. After titration, the $\%$ nitrogen was calculated using the formula:

$$
\% \text { Nitrogen }=\left(V s-V_{B}\right) \times M_{\text {acid }} \times 0.01401 \times 100 \mathrm{~W}
$$

Where, Vs = Volume $(\mathrm{ml})$ of acid required to titrate sample; $\mathrm{V}_{\mathrm{B}}=$ Volume $(\mathrm{ml})$ of acid required to titrate the blank; $\mathrm{M}_{\text {acid }}=$ Molarity of acid; $\mathrm{W}=$ Weight of sample (g).

Then, percentage crude protein in the sample was calculated from the $\%$ Nitrogen as $\%$ crude protein $=\% \mathrm{~N} \mathrm{x}$ $\mathrm{F}$, where, $\mathrm{F}$ (conversion factor), is equivalent to 6.25 [11].

\subsubsection{Determination of Crude Fat}

The crude fat in the powdered sample was determined using Soxhlet extraction for 24 hour. Approximately, $3.0 \mathrm{~g}$ of samples were weighed accurately into labeled thimbles. The dried boiling flasks $(250 \mathrm{ml})$ were weighed correspondingly and filled with about $150 \mathrm{ml}$ of petroleum ether (boiling point $40-60{ }^{\circ} \mathrm{C}$ ). The extraction thimbles were plugged tightly with cotton wool. After that, the Soxhlet apparatus was assembled and allowed to reflux for $24 \mathrm{hrs}$. The thimble was removed with care and petroleum ether collected from the top container and drained into another container for re-use. After that, the boiling flask was heated in a hot air oven until it was almost free of petroleum ether. After drying, it was cooled in a desiccator and weighed [10].

The $\%$ fat in the sample was calculated using the formula:

$$
\text { Fat }(\%)=(\text { Wt. of fat } / \text { Wt. of original sample }) \times 100
$$

\subsubsection{Determination of Crude Fiber}

About $2 \mathrm{~g}$ fat free sample of powdered onion was taken into a fiber flask and $100 \mathrm{ml}$ of $0.255 \mathrm{~N} \mathrm{H}_{2} \mathrm{SO}_{4}$ was added. Then the mixture was heated under reflux with heating 
mantle for one hour. The hot mixture was filtered through a fiber sieve cloth. The difference obtained was thrown off and the residue was returned to the flask to which $100 \mathrm{ml}$ of $0.313 \mathrm{M} \mathrm{NaOH}$ was added and heated under reflux for another one hour. The mixture was filtered through a fiber sieve cloth and $10 \mathrm{ml}$ of acetone was added to dissolve any organic constituent. The residue was washed with $50 \mathrm{ml}$ of hot water twice on the sieve cloth before it was finally transferred in the pre-weighted crucible. The crucible with residue was oven dried at $105{ }^{0} \mathrm{C}$ overnight to drive off moisture. The oven dried crucible containing the residue was cooled in a desiccators and latter weighted $\left(\mathrm{W}_{1}\right)$ for ashing at $550{ }^{\circ} \mathrm{C}$ for 4 hours [11].

The crucible containing white and grey ash (free of carbonaceous material) was cooled in a desiccator and weighted to obtain $\mathrm{W}_{2}$. The $\%$ of crude fiber was calculated as follows-

$$
\text { Fiber }(\%)=\left[\left\{\left(\mathrm{W}_{1}-\mathrm{W}_{2}\right) / \mathrm{Wt} \text {. of sample }\right\} \times 100\right]
$$

\subsubsection{Determination of Total Sugar}

Total sugar is determined by volumetric method (the Lane-Eynon method). The method is used for the quantitative determination of total sugar samples. Results are expressed as percentage of sugar in $100 \mathrm{~g}$ of sample.

Reagents: Hydrochloric acid, Sucrose, Copper sulfate solution, alkaline tartrate solution, Fehling's solution, Sodium hydroxide, Sugar standard solution.

Method: The method involves the inversion of sugars present in food samples with hydrochloric acid. The sugar present in a specified volume of the hydrolyzed solution was used to reduce copper in the Fehling's solution previously standardized with working standard invert sugar solution. Excess copper was back titrated with the standard sugar solution. The difference in the volume of standard sugar used for the standardization and for back titration is a measure of total sugar content of the sample [11, 12].

$$
\text { Calculation: }
$$

$$
\begin{aligned}
\text { Total sugar }(\text { g per } 100 \mathrm{~g}) & =(\mathrm{F}-\mathrm{M}) \times \mathrm{I} \times 250 \times 100 \times 100 /(\mathrm{W} \\
& \times \mathrm{A} \times 50)
\end{aligned}
$$

Where, $\mathrm{F}=$ volume of standard sugar solution required to reduce $10 \mathrm{~mL}$ mixed Fehling's solution; $\mathrm{M}=$ volume of standard sugar solution used in back titration of the sample; I = gram sugar per $\mathrm{mL}$ working standard solution; $\mathrm{W}=$ weight of sample.

\subsubsection{Determination of Vitamin-C}

The method is applicable to determination of reduced ascorbic acid. Ascorbic acid reduces oxidation-reduction indicator dye, 2, 6 - dichloroindophenol to colorless solution. After the ascorbic acid was oxidized to dehydroascorbic acid, excess dye remains pink in acid solution. At end point, excess unreduced dye was rose pink in acid solution. Vitamin was extracted and titration performed in presence of $\mathrm{HPO}_{3}-\mathrm{CH}_{3} \mathrm{COOH}$ or $\mathrm{HPO}_{3}-\mathrm{CH}_{3} \mathrm{COOH}-\mathrm{H}_{2} \mathrm{SO}_{4}$ solution to maintain proper acidity for reaction and to avoid auto oxidation of ascorbic acid at high $\mathrm{pH}$.

Reagents: Ascorbic acid Standard Solution, $1 \mathrm{mg} / \mathrm{mL}$, 2,6-Dichloroindophenol Standard Solution, Metaphosphoric acid-acetic acid solution, Sulfuric acid, 0.3 N, Metaphosphoric acid-acetic acid-sulfuric acid solution.

Sample preparation: Test sample was weighted in 100 $\mathrm{mL}$ beaker and homogenized with approximately $50 \mathrm{~mL}$ $\mathrm{HPO}_{3} . \mathrm{CH}_{3} \mathrm{COOH}$ solution using tissue homogenizer until sample was in suspension. Homogenized sample transferred into a $100 \mathrm{~mL}$ volumetric flask and diluted to volume with $\mathrm{HPO}_{3} \cdot \mathrm{CH}_{3} \mathrm{COOH}$ solution.

Blank test: $7 \mathrm{~mL} \mathrm{HPO}$. $\mathrm{CH}_{3} \mathrm{COOH}$ solution into a $50 \mathrm{~mL}$ Erlenmeyer flask was measure in triplicate and titrated with indophenol solution until rose pink color persist for 10 seconds. The volumes $(\mathrm{mL})$ used was recorded and mean was calculated.

Titration of the sample: Aliquots of $5 \mathrm{~mL}$ of sample was pipette out containing $\mathrm{Ca} 2 \mathrm{mg}$ ascorbic acid into each of two $50 \mathrm{ml}$ Erlenmeyer flasks. Enough $\mathrm{HPO}_{3} \cdot \mathrm{CH}_{3} \mathrm{COOH}$ solution was added to make a total volume of $7 \mathrm{~mL}$. Indophenol solution was titrated using a digital burette. The volume was recorded in $\mathrm{mL}$ [11].

Calculation of $\mathrm{mg}$ ascorbic acid per $\mathrm{mL}$ indophenols solution (Factor):

$\mathrm{mg} / \mathrm{mL}$ Ascorbic acid standard = Weight Ascorbic acid standard / Total dilution volume

Factor $=[\{2 \mathrm{~mL} \times \mathrm{mg} / \mathrm{mL}$ ascorbic acid standard $\} /\{$ Mean vol. (mL) indophenols std. - Mean vol. (mL) blank $\}]$

Calculation of $\mathrm{mg}$ ascorbic acid per $100 \mathrm{~g}$ sample:

$\mathrm{mg} / 100$ Vit $\mathrm{C}=[\{($ Vol. indophenol solution - blank $) \times$ factor $\times$ Total vol. $\times$ Dil. $\times 100\} /($ Weight $\times$ Aliquot $)]$

\subsubsection{Determination of Ash Content}

Ash is an inorganic residue remaining after the material has been completely burnt at a temperature of $550{ }^{\circ} \mathrm{C}$ in a muffle furnace. It is the aggregate of all non-volatile inorganic elements. About $8 \mathrm{~g}$ of finely ground dried sample was weighed into a porcelain crucible and incinerated at $55{ }^{\circ} \mathrm{C}$ for $6 \mathrm{hr}$ in an ashing muffle furnace until ash was obtained. The ash was cooled in desiccators and reweighed [11].

The $\%$ ash content in the onion sample was calculated as follows:

$$
\text { Ash }(\%)=(\text { Wt. of ash } / \text { Wt. of sample taken }) \times 100
$$

\subsubsection{Determination of Silica}

Reagents: Dilute hydrochloric acid, Silver nitrate solution.

Procedure: $25 \mathrm{~mL}$ of dilute $\mathrm{HCl}$ was added in the dish containing total ash and boiled covering the dish with a watch glass to prevent spattering. It was then allowed to cool and filtered the contents of the dish through an ash less filter paper (medium fine). The filter paper was washed with hot water until the washings were free from $\mathrm{HCl}$ as tested by silver nitrate solution and returned to the dish. It 
was evaporated carefully on a water bath and ignited in a muffle furnace at $550{ }^{\circ} \mathrm{C}$ for 1 hour. The dish was cooled in a desiccator and weighted. Repeated the operation of ignition for $1 \mathrm{hr}$, cooling and weighing till the difference in weight between two successive weighing's was less than $0.001 \mathrm{~g}$. The lowest weight was noted [11].

Calculation: Ash insoluble in dil. $\mathrm{HCl}$ (on dry basis) \% by wt. $=\left[\left\{\left(\mathrm{W}_{4}-\mathrm{W}\right) /\left(\mathrm{W}_{1}-\mathrm{W}\right)\right\} \times 100 \times\{100 /(100-\mathrm{M})\}\right]$

Where, $\mathrm{W}=\mathrm{Wt}$. of empty dish; $\mathrm{W}_{1}=\mathrm{Wt}$. of dish + Sample; $\mathrm{W}_{4}=\mathrm{Wt}$. of dish + Acid insoluble ash; $\mathrm{M}=$ Percent moisture content.

\subsubsection{Determination of Total Carbohydrate}

The total percentage carbohydrate content in the onion sample was determined by the difference method. This method involved adding the total values of crude protein, lipid, crude fiber, moisture and ash constituents of the sample and subtracting it from 100 . The value obtained is the percentage carbohydrate constituent of the sample [13].

Thus:

$$
\begin{gathered}
\% \text { carbohydrate }=100-(\% \text { moisture }+\% \text { crude fiber }+\% \\
\text { protein }+\% \text { lipid }+\% \text { ash })
\end{gathered}
$$

\subsection{Determination of Mineral Content of Onion Samples}

The mineral content of the onion samples were determined using the methods of the AOAC. Calcium, Iron, Copper, Manganese, Zinc, Sodium and Potassium were determined by Atomic Absorption Spectrometry. Briefly, about $1.0 \mathrm{~g}$ of sample was first digested with $20 \mathrm{ml}$ of acid mixture $\left(650 \mathrm{ml} \mathrm{Conc} . \mathrm{HNO}_{3}, 80 \mathrm{ml}\right.$ Perchloric acid, $20 \mathrm{ml}$ $\mathrm{H}_{2} \mathrm{SO}_{4}$ ) by weighing the sample into a digestion flask followed by addition of the $20 \mathrm{ml}$ acid mixture. The digestion flask containing the sample and the digestion acid mixture was heated until a clear digest was obtained. The digest was later diluted with distilled water to $500 \mathrm{ml}$ mark. After obtaining the digest, aliquots of the clear digest were used for atomic absorption spectrophotometry using filters that matched the different elements. The concentrations of minerals were determined with their calibration curves prepared with their standard solutions. The percentage values were later calculated by multiplying the concentrations by 100 [11].

Phosphorus was determined by Molybdate Method. Briefly, about $0.5 \mathrm{ml}$ of the mineral digest and $9.5 \mathrm{ml}$ of $10 \%$ trichloroacetic acid were put into a test tube. This was followed by agitation for $5 \mathrm{~min}$. and then filtered through a filter paper. About $5 \mathrm{ml}$ of the filtrate was then measured into a cuvet. Also, $5 \mathrm{ml}$ of trichloroacetic acid and $5 \mathrm{ml}$ of the working standard were also measured into two cuvets which served as a blank and standard, respectively. About $0.5 \mathrm{ml}$ of molybdate reagent was then added to each test tube and mixed. Similarly, $0.2 \mathrm{ml}$ of sulfuric acid reagent was added and the contents were stoppered, mixed and allowed to stand for $10 \mathrm{~min}$. The absorbance of the test sample and standard were read in a Spectrophotometer at
$660 \mathrm{~nm}$ with the blank set at zero [14].

The \% Phosphorus (P) was then calculated as:

$\begin{aligned} \% \text { Phosphorus }(\mathrm{P}) & =(\text { Absorbance of test sample } / \text { Absorbance of } \\ \text { standard }) & \times \text { Conc. of Standard }(5 \mathrm{mg} / \mathrm{dl}) \times 100\end{aligned}$

\subsection{Determination of Energy Value of Onion Samples}

The energy value of the samples was determined by multiplying the protein content by 4 , carbohydrate content by 4 and fat content by 9 [11].

Energy Value $=($ Crude protein $\times 4)+($ Total carbohydrate $\times$ 4) $+($ Crude fat $\times 9)$

\section{Results}

Results of the proximate composition in studied sample materials are given in Table 1, while the results of the presence of various mineral elements are given in Table 2.

The proximate analysis of the two varieties of Allium cepa $\mathrm{L}$. revealed very high moisture contents, ranging from $82.99 \%$ in the Bangladeshi onion to $82.77 \%$ in the Indian onion. There was a substantial difference in the total sugar contents of both varieties, with the Bangladeshi variety having a higher value $(4.74 \%)$. The crude protein and crude fiber contents were higher in the Bangladeshi Allium cepa $\mathrm{L}$. (2.62\% and $2.65 \%$ respectively) compared to the Indian variety. Whereas, the ash, carbohydrate and silica contents were lower in the same variety $(0.205 \%$, $14.146 \%$ and $0.032 \%$ respectively) compared to the Indian variety. All these parameters showed no major differences in both varieties. Moreover, the carbohydrate contents were comparable and did not indicate any remarkable distinction between the two varieties. Vitamin analysis expressed that the level of vitamin $\mathrm{C}$ were higher in the Bangladeshi variety of Allium cepa L. compared to the Indian variety (Table 1 ).

Analysis of the mineral contents showed that there was some variation from Bangladeshi - Indian Allium cepa L. in the contents of calcium, $\mathrm{Ca},(46.9-25.7 \mathrm{mg})$; phosphorus, $\mathrm{P}$, (50.6 - $30.3 \mathrm{mg})$; sodium, Na, (3.86 - 3.1 $\mathrm{mg})$; potassium, K, (140 - $129 \mathrm{mg})$; iron, Fe (0.6 - $0.24 \mathrm{mg})$; copper, $\mathrm{Cu},(0.04-0.1 \mathrm{mg})$; manganese, $\mathrm{Mn},(0.2-0.14 \mathrm{mg})$ and zinc, $\mathrm{Zn}$, (0.2 - $0.4 \mathrm{mg})$. Calcium, phosphorus, sodium, potassium, iron and manganese were higher in the Bangladeshi variety of Allium cepaL. While copper and zinc were higher in the Indian variety (Table 2).

The energy value calculated was about $67.419 \mathrm{Kcal} / 100$ $\mathrm{g}$ in Bangladeshi variety and $72.132 \mathrm{Kcal} / 100 \mathrm{~g}$ in Indian variety as follows-

For Bangladeshi onion,

Energy value $=$

$($ Crude protein $\times 4)+($ Total carbohydrate $\times 4)+($ Fat $\times 9)$ $=67.418537 \mathrm{Kcal} / 100 \mathrm{~g}$

For Indian onion,

Energy value $=$

$($ Crude protein $\times 4)+($ Total carbohydrate $\times 4)+($ Fat $\times 9)$ $=72.132049 \mathrm{Kcal} / 100 \mathrm{~g}$ 
Table 1. Proximate composition of two varieties of onion*

\begin{tabular}{ccc}
\hline & & SAMPLE \\
\cline { 2 - 3 } PARAMETER & BANGLADESHI ONION & INDIAN ONION \\
\hline Total Moisture Content & $82.99 \mathrm{~g} \pm 0.05$ & $82.77 \mathrm{~g} \pm 0.07$ \\
Crude Protein & $2.62 \mathrm{~g} \pm 0.3$ & $1.489 \mathrm{~g} \pm 0.4$ \\
Crude Fat & $0.4 \mathrm{~g} \pm 0.06$ & $0.721 \mathrm{~g} \pm 0.05$ \\
Total Carbohydrate & $14.146 \mathrm{~g} \pm 0.07$ & $14.772 \mathrm{~g} \pm 0.04$ \\
Crude Fiber & $2.646 \mathrm{~g} \pm 0.3$ & $1.659 \mathrm{~g} \pm 0.8$ \\
Ash Content & $0.205 \mathrm{~g} \pm 0.08$ & $0.248 \mathrm{~g} \pm 0.1$ \\
Total Sugar & $4.74 \mathrm{~g} \pm 0.5$ & $2.32 \mathrm{~g} \pm 0.2$ \\
Silica & $0.032 \mathrm{~g} \pm 0.007$ & $0.034 \mathrm{~g} \pm 0.005$ \\
Ascorbic Acid (Vitamin-C) & $6.5 \mathrm{mg} \pm 0.3$ & $5.7 \mathrm{mg} \pm 0.5$ \\
\hline
\end{tabular}

*Nutritional value per $100 \mathrm{~g}$ of onion; values are mean \pm standard deviation for three replications.

Table 2. Mineral composition of studied onion varieties*

\begin{tabular}{ccc}
\hline & & SAMPLE \\
PARAMETER & BANGLADESHI ONION & INDIAN ONION \\
\cline { 2 - 3 } Calcium (Ca) & $46.9 \mathrm{mg} \pm 0.2$ & $25.7 \mathrm{mg} \pm 0.3$ \\
Phosphorus (P) & $50.6 \mathrm{mg} \pm 0.3$ & $30.3 \mathrm{mg} \pm 0.5$ \\
Sodium (Na) & $3.86 \mathrm{mg} \pm 0.5$ & $3.1 \mathrm{mg} \pm 0.4$ \\
Potassium (K) & $140 \mathrm{mg} \pm 1$ & $129 \mathrm{mg} \pm 2$ \\
Iron (Fe) & $0.6 \mathrm{mg} \pm 0.1$ & $0.24 \mathrm{mg} \pm 0.5$ \\
Copper (Cu) & $0.04 \mathrm{mg} \pm 0.01$ & $0.1 \mathrm{mg} \pm 0.07$ \\
Manganese (Mn) & $0.2 \mathrm{mg} \pm 0.02$ & $0.14 \mathrm{mg} \pm 0.01$ \\
Zinc (Zn) & $0.2 \mathrm{mg} \pm 0.02$ & $0.4 \mathrm{mg} \pm 0.03$ \\
Ca/P** & 0.93 & 0.85 \\
Na/K ${ }^{* *}$ & 0.03 & 0.02 \\
Calcium (Ca) & $46.9 \mathrm{mg} \pm 0.2$ & $25.7 \mathrm{mg} \pm 0.3$ \\
\hline
\end{tabular}

*Nutritional value per $100 \mathrm{~g}$ of onion; values are mean \pm standard deviation for three replications. ${ }^{* *}$ Calculated values.

\section{Discussion}

The proximate analysis of the two varieties of Allium cepa $\mathrm{L}$. showed high carbohydrate contents and the highest $(14.772 \%)$ was found in the Indian variety. These high amounts of carbohydrates in both varieties investigated confer on them, significant roles to human health. This is because, apart from the supply of energy, carbohydrates are also needed in numerous biochemical reactions not directly concerned with energy metabolism. In addition, these carbohydrates may serve as substrates for the production of aromatic amino acids and phenolic compounds through the Shikimic acid pathway and this may confer high phenolic and antioxidant potentials on both varieties. Thus the carbohydrate levels of the studied samples suggest its usefulness as alternative source of glucose.

The level of protein in the two varieties of Allium cepa $\mathrm{L}$. was not too high; however the protein content of the Bangladeshi variety $(2.62 \%)$ was higher than that of the Indian variety $(1.489 \%)$. The higher protein contents of Bangladeshi onion studied, indicates that its intake can contribute to the formation of hormones which controls a variety of body functions such as growth, repair and maintenance (replacement of wear and tear of tissues) of body. In addition, it may be useful as a preferred option to animal proteins for diabetics as the later tend to be high in 
saturated fats. This confirms that onion is an energy-giving food.

Crude fiber is increasingly being recognized as a useful tool for the control of oxidative processes in food products and as functional food ingredient. The presence of crude fiber in the diet is necessary for digestion and for elimination of wastes. The contraction of muscular walls of the digestive tract is stimulated by fiber, thus counteracting constipation [15]. In addition, it decreases the absorption of cholesterol from the gut in addition to delaying the digestion and conversion of starch to simple sugars, an important factor in the management of diabetes. It may reduce cerium cholesterol levels too. Crude fiber also functions in the protection against cardiovascular disease, colorectal cancer and obesity. Thus the high percentage fiber contents in the Bangladeshi variety of onion $(2.646 \%)$ makes it more effective and useful than the Indian one $(1.659 \%)$ in the management of diabetes mellitus, colorectal cancers and weight reduction in obsessed individuals, and this is the most significant finding in this present study.

The high moisture content of both Allium cepa L. varieties reveals that they need care for appropriate preservation as they will be prone to deterioration. It makes them susceptible to infection by micro-organisms. The high water content helps the body as the body does not need to use some of its own water to digest them. This means that the body uses less energy and resources to digest and can then assimilate all the nutrients much faster. Less pressure is therefore put on the digestive system [16].

The study of ash content is very important to the extent that it provides an insight into the nutritionally important inorganic mineral elements, which are presented in Table 2. It was reported that the ash content of a food sample gives an idea of the mineral elements present in the food sample [17]. In the present study, both the varieties exhibited low level of ash content. Yet, Indian variety of Allium cepa L. could be promising sources of essential or non - essential mineral elements as it holds higher level of ash content $(0.248 \%)$ than that of Bangladeshi one $(0.205 \%)$.

The effect of excess intake of crude fat has some well-established health implications especially for the overweight. The consumption of excess amounts of fats has been recognized as the most important dietary factor aiding increased level of cholesterol. Besides the cholesterol implications due to high fat intake, obesity is a factor in the causation of disease [18]. In this regard, Bangladeshi variety of Allium cepa L. could be said to be better preferred as it may reduce the risk of coronary heart disease and lower the risk of hypertension due to its lower crude fat content of about $0.04 \%$.

The total sugar contents in both varieties of Allium cepa L. were excessively high and the highest $(4.74 \%)$ was found in the Bangladeshi variety.

Silica stimulates the formation of collagen, a protein that gives bones their strength and flexibility, joint cartilage its cushioning ability, and a scaffold upon which bone mineralization occurs [19]. In this study, silica levels were found low in the two varieties of Allium cepa $\mathrm{L}$. with the Bangladeshi variety having the lowest level (0.032\%).

Allium cepa L. constitutes an important part of the human diet and is source of vitamin $\mathrm{C}$ which is involved in collagen synthesis, bone and teeth calcification. The vitamin content analysis showed that vitamin $\mathrm{C}$ was higher in the Bangladeshi variety than the Indian variety; therefore, the Bangladeshi variety may be favored here.

The mineral elemental composition revealed that calcium and iron that are required for bone development and hemoglobin production respectively [20] were higher in the Bangladeshi variety of Allium cepa L., the same thing applied to phosphorous that is an important component of energy intermediates [21].

Sodium was also observed to be considerably lower than potassium in both varieties of Allium cepa L. Low sodium diet has been reported to be beneficial in the prevention of high blood pressure [22] and high potassium has been reported to have a protective effect against excessive sodium intake.

Zinc which plays a vital role in the proper functioning of the reproductive system[23] and nucleic acid metabolism [24] was higher in the Indian variety. $\mathrm{Zn}$ is also beneficial as a membrane stabilizer and a stimulator of the immune response. Copper was also observed to be lower than manganese in both varieties of Allium cepa L. Copper is quite low in the Bangladeshi variety but moderate in the Indian one. It is a component of many enzyme systems such as cytochrome oxidase, lysyl oxidase \& ceruloplasmin, an iron-oxidizing enzyme in blood [25]. Manganese, an essential element for hemoglobin formation, was reported comparable in both varieties.

The ratios of sodium to potassium $(\mathrm{Na} / \mathrm{K})$ and calcium to phosphorus $(\mathrm{Ca} / \mathrm{P})$ are also shown in Table $2 . \mathrm{Na} / \mathrm{K}$ ratio in the body is of great concern for prevention of high blood pressure; $\mathrm{Na} / \mathrm{K}$ ratio less than one is recommended. Hence, in the present study, both the samples would probably reduce high blood pressure disease because they had $\mathrm{Na} / \mathrm{K}$ less than one. Modern diets which are rich in animal proteins and phosphorus may promote the loss of calcium in the urine [26]. This had led to the concept of the $\mathrm{Ca} / \mathrm{P}$ ratio. If the $\mathrm{Ca} / \mathrm{P}$ ratio is low (low calcium, high phosphorus intake), more than the normal amount of calcium may be lost in the urine, decreasing the calcium level in bones. Food is considered good if the ratio is above one and poor if the ratio is less than 0.5 [27]. The $\mathrm{Ca} / \mathrm{P}$ ratio in the present study ranged between 0.93 to 0.85 indicating that both of them would serve as moderate sources of minerals for bone formation.

Energy value of a food measures its value to the body as a fuel and it measures the inherent chemical energy inherent in the bonds of the organic compounds of foods such as their protein, carbohydrate and fat constituents as well as minor constituents such as organic acids. Both the varieties showed higher energy value and the highest were found in the Indian variety having about $72.132 \mathrm{Kcal} / 100 \mathrm{~g}$. 


\section{Conclusions}

On the basis of the comparative assessment, it can be disclosed from this work that Bangladeshi Allium cepa $\mathrm{L}$. is better due to its high proteins, fibers, carbohydrates, sugar and moisture contents with an adequate quantity of vitamins and minerals with potentials to meet the nutritional requirements of human health. However, the Indian variety of Allium cepa L. was still within the acceptable standard in terms of energy value. The overall interpretation of this present investigation may offer a scientific basis for increased and versatile utilization of these carbohydrate-rich onions as a food component and carbohydrate supplement.

\section{Acknowledgement}

We wish to gratefully acknowledge Bangladesh Council of Scientific and Industrial Research (BCSIR), Dhaka for their helpful contribution in the Laboratory analyses.

\section{References}

[1] L. M. Mogren, M. E. Olssen, and U. E. Gertsson, "Effects of cultivar, lifting time and nitrogen fertiliser level on quercetin content in onion (Allium cepa L.) at lifting," Journal of the Science of Food and Agriculture, vol. 87, pp. 470-476, 2007.

[2] A. K. M. Hossain, and J. Islam, "Status of Allium cepa production in Bangladesh," Hort. Abst., vol. 58, pp. 33-36, 1994.

[3] M. Asaduzzaman, M. M. Hasan, and M. Moniruzzaman, "Quality seed production of onion (Allium cepa L.): an integrated approach of bulb size and plant spacing," J. Agric. Res., vol. 50(1), pp. 119-128, 2012.

[4] V. E. Rubatzky, and M. Yamaguchi, World Vegetables, 3rd ed., New York: Chapman and Hall, 1997.

[5] K. E. Campos, Y. S. Diniz, A. C. Cataneo, L. A. Faine, M. J. Alves, and E. L. Novelli, "Hypoglycaemic and antioxidant effects of onion, Allium cepa: Dietary onion addition, antioxidant activity and hypoglycaemic effects on diabetic rats,” Int. J. Food Sci. Nutr., vol. 54, pp. 241-246, 2003.

[6] P. L. T. M. Janssen, R. P. Mensink, and F. J. J. Cox, "Effects of the flavonoids quercetin and apigenin on hemostasis in healthy volunteers: results from an in vitro and a dietary supplement study," Am. J. Clin. Nutr., vol. 67, pp. 255-262, 1998.

[7] A. M. Ismail, A. A. Sedki, and A. G. Abdallah, "Influence of black seed, garlic and onion supplementation on reproductive performance in rabbits," Egypt J. Agric. Res., vol. 81, pp. 1193-1207, 2003.

[8] J. L. Brewster, Onions and other vegetable Alliums, 1st ed., Wallingford, UK: CAB International, 1994, pp. 212.

[9] C. O. Eleazu, A. I. Ikpeama, J. U. Amajor, and K. C. Eleazu, "Proximate composition, essential oils and energy value of 10 new varieties of ginger (zingiber officinale roscoe)," International Journal of Biology, Pharmacy and Allied Science (IJBPAS), vol. 1(9), pp. 1293-1303, 2012.
[10] AACC, Approved methods of the American Association of Cereal Chemists, vol. 1 (Method No. 30-25, 44-15A), USA: American Association of Cereal Chemists, 2000.

[11] AOAC, Official Methods of Analysis of Association of Official Analytical Chemists, 15th ed., Arlington Va, USA: AOAC, 1990, pp. 1-50.

[12] H. Greenfield, and D. A. T. Southgate, Food composition data: production, management and use, UK: Elsevier Applied Science, 1992.

[13] S. Sarkiyayi, and T. M. Agar, "Comparative analysis on the nutritional and anti-nutritional contents of the sweet and bitter cassava varieties," Advance Journal of Food Science and Technology, vol. 2(6), pp. 328-334, 2010.

[14] A. O. Oko, B. E. Ubi, A. A. Efisue, and N. Dambaba, "Comparative analysis of the chemical nutrient composition of selected local and newly introduced rice varieties grown in ebonyi state of Nigeria," International Journal of Agriculture and Forestry, vol. 2(2), pp. 16-23, 2012.

[15] S. Ponnusamy, and T. Vellaichamy, "Nutritional assessment, polyphenols evaluation and antioxidant activity of food resource plant Decalepis hamiltonii Wight \& Arn," Journal of Applied Pharmaceutical Science, vol. 2(5), pp. 106-110, 2012.

[16] W. K. J. Kwenin, M. Wolli, and B. M. Dzomeku, "Assessing the nutritional value of some African indigenous green leafy vegetables in Ghana," Journal of Animal \& Plant Sciences, vol. 2(2), pp. 16-23, 2011.

[17] C. O. Edeogu, F. C. Ezeonu, A. N. C. Okaka, C. E. Ekuma, and S. O. Elom, "Proximate composition of staple food crops in Ebonyi State (South Eastern Nigeria)," International Journal of Biotechnology and Biochemistry, vol. 3(1), pp. 1-8, 2007.

[18] G. M. Wardlaw, and M. Kessel, Prospective in Nutrition, 5th ed., Boston: McGraw-Hill, 2002, pp. 278.

[19] S. Sripanyakorn, R. Jugdaohsingh, R. P. H. Thompson, and J. J. Powell, "Dietary silicon and bone health," British Nutrition Foundation, Nutrition Bulletin, vol. 30(3), pp. 222-230, 2005.

[20] E. Helena, "Iron imbalance can lead to clinical depression," Journal of Health and Fitness, vol. 42, pp. 48-102, 2008.

[21] C. P. Vance, C. Uhde-Stone, and D. L. Allan, "Phosphorus acquisition and use: critical adaptations by plants for securing a nonrenewable resource," New Phytologist, vol. 157, pp. 432-449, 2003.

[22] A. H. Lichtenstein, L. J. Appel, M. Brands, M. Carnethon, S. Daniels, H. A. Franch, B. Franklin, P. Kris-Etherton, W. S. Harris, B. Howard, N. Karanja, M. Lefevre, L. Rudel, F. Sacks, L. Van Horn, M. Winston, and J. Wylie-Rosett, "Summary of American heart association diet and lifestyle recommendations revision," Arteriosclerosis, Thrombosis and Vascular Biology, vol. 26, pp. 2186-2191, 2006.

[23] M. Hambidge, "Human zinc deficiency," Journal of Nutrition, vol. 130, pp. 1344S-1349S, 2006.

[24] T. M. S. Atukorala, and U. S. Waidyanatha, "Zinc and copper content of some common foods," J. Nat. Sci. Coun. Sri Lanka, vol. 15 , pp. 61-69, 1987. 
[25] C. F. Mills, "Biochemical roles of trace elements," Prog. Clin. Biol. Res., vol. 77, pp. 179-188, 1981.

[26] M. E. G. Shills, and V. R. Young, Modern nutrition in health and disease. In: Nutrition (Ed. Neiman, D.C., Buthepodorth, D.E. and Nieman, C.N.), Dubugue, USA: WmC. Brown publishers, 1988, pp. 276-282.
[27] D. C. Nieman, D. E. Batterworth, and C. N. Nieman, Nutrition, Dubugue, USA: Wmc. Brown Publishers, 1992, pp. 237-312. 